\title{
Regulating and supporting services and disservices: customary approaches to valuation, and a few surprising case-study results
}

\author{
Colin Price
}

From Third International Congress on Planted Forests

Bordeaux, France; Dublin, Ireland; and Porto and Estoril, Portugal. 16-21 May 2013

\begin{abstract}
For economists, what matters is not how ecosystem services are classified, but what change in human well-being results from increasing, reducing or qualitatively varying their supply. Eight general approaches are available for valuing non-market effects: marketable benefits may be generated or lost elsewhere in the economy; costs may be imposed or alleviated elsewhere; costs willingly incurred by past decision-makers may be taken as indicating their valuation; sufficiently similar services may be traded elsewhere; consumers may voluntarily support "good causes", including through price premia for environmentally friendly production; individuals may be asked their hypothetical willingness to pay for change in an environmental condition; experts may estimate what a reasonable willingness to pay might be; market products may exist which give access to ecosystem services or escape from disservices. All approaches have drawn criticism, which itself has drawn rebuttal and improvement from their proponents. All approaches have been applied to the regulating and supporting effects of forests on the qualities of land, watercourses, atmosphere and biological resources. Enormous valuations may be given when consumers attribute symbolic significance to or derive a "warm glow" from favouring a particular ecosystem. This may arise in response to questionnaires or by paying premia for certified goods. But directly elicited or implicitly accepted willingness to pay for ecosystem services requires consumers to have improbable understanding of processes: willingness to pay for final products, services or disservices delivered to the consumer is a more appropriate basis. Planted forests may have adverse as well as beneficial effects on watercourses, e.g. by reducing hydroelectricity output. With rapidly rising carbon prices, the carbon transactions of a single commercial forest cycle may have negative overall value. These examples illustrate that results may be surprising, but all of them are context dependent. Foresters should not regard economics as intrinsically hostile to ecosystem service provision, nor assume that forestry is always favoured by economic valuation of those services.
\end{abstract}

\section{Introduction: ecosystems and services}

Ecosystem services are now routinely placed under the four categories recognised in Millennium Ecosystem Assessment (2005). Provisioning services generate physical products: what used to be called goods, including timber, and non-timber forest products. Arguably, since economics traditionally separated goods (things) from services (actions), this provisioning category is an unhelpful blurring of a long-understood distinction.

Correspondence: c.price@bangor.ac.uk

90 Farrar Road, Bangor, Gwynedd LL57 2DU, UK
Regulating services are processes that improve the physical environment for specific human purposes: effects on attributes of atmosphere, watercourses and land surfaces, and on populations of biological agents, such as pests, which have economic significance. Formerly, such effects were called "forest influences" (Kittredge, 1948).

Cultural services are sensory experiences of the ecosystem that enhance human well-being aesthetically and spiritually.

Supporting services aid the functioning of ecosystems, without delivering any products or varying any environmental conditions that directly benefit humans. Examples

\section{SpringerOpen ${ }^{\circ}$}

(C) 2014 Price; licensee Springer. This is an Open Access article distributed under the terms of the Creative Commons Attribution License (http://creativecommons.org/licenses/by/2.0), which permits unrestricted use, distribution, and reproduction in any medium, provided the original work is properly cited. 
include gene conservation, soil formation and nutrient recycling. To illustrate, humans derive no direct pleasure from observing nutrient recycling in forests, but rather from the forest products and environmental conditions that nutrient cycling supports. If the contribution of supporting services to generation of direct human benefits were evaluated and added to the direct value, there would be illegitimate double-counting of benefit. This ought to be evident, but where teams of researchers independently value different ecosystem services, such double-counting might occur.

Services arising within a landscape may be improperly attributed to one particular configuration of ecosystem. For example, in the Corsican pine (Pinus nigra var. maritima (Ait.) Melville) forest of Newborough, North Wales, dune slacks contain the national rarity, round-leaved wintergreen (Pyrola rotundifolia L.). But the plant is also found in the adjoining, unforested national nature reserve. The agencies protecting both these ecosystem configurations note the valuable presence of the plant within their own boundaries. But, whatever other services the forest itself provides, the entire benefits of the wintergreen's survival should not be included. The key question is: what changes in the delivery of ecosystem services, when the configuration of land use changes?

The concern of this paper is with regulating and supporting services: provisioning and cultural services are mentioned only in passing. It reviews illustrative results from numerous published and a few unpublished case studies, with the objective of highlighting the problems, as well as the clarifications, that may arise through valuation. Some pointers are given to how problems might be addressed.

\section{Approaches to valuation}

Environmental economists are often asked: "How can you put a price on the song of a nightingale heard in a moonlit wood?" - or any similarly emotive example of an ecosystem service. The question is rhetorical: the enquirer neither expects an answer, nor wants one. The economist is meant to retreat, baffled, defeated, conspicuously shallow in thinking. One possible, non-rhetorical answer, however, is: "There are eight basic approaches. Do you want to consider them all?" These approaches are listed below, with examples relevant to regulating and supporting services. Some examples date back many years, showing that recent preoccupations with ecosystem valuation build on a long tradition in economics.

Many reviews and applications of such approaches have been written in the $21^{\text {st }}$ century, e.g. Willis et al. (2003); Millennium Ecosystem Assessment (2005); Watson and Albon (2011); Eastwood et al. (2013). The last-mentioned emphasises the variability of values with context: results such as those reported below need not apply in different physical and social contexts, though the approaches themselves remain relevant.

\section{Marketable benefits are created or lost elsewhere in the economy through ecosystem services}

A straightforward example is wind shelter from planted trees. Significant shelter may be provided at the boundary between forest and pastoral land ownerships, shelter then being a classical economic externality: the benefit is matched by neither monetary remuneration nor benefit in kind to the forest owner. However, reduced wind-speed reduces heat loss from out-wintered livestock, which reduces energy consumption for temperature maintenance, reducing winter weight loss and increasing survival of offspring. Applying sale prices to the increased output gives the economic consequence of shelter. Note immediately that good ecosystem economics is not opposed to good ecosystem science, but is necessarily based on it. Energy conservation enters the valuation via measurement of physical response to changed environment. In an experiment in Eddleston Forest near Edinburgh in the 1980s, "artificial sheep" were used in open and forest conditions, the energy consumption entailed in maintaining mammalian body temperature being measured, inside simulated insulating layers.

Pollination by insects is a regulating service for economic crops. Planted forests may provide islands of mixed and durable habitat for pollinators, in a sea of single-species agricultural crops (Price and Willis, 1994). The value of services is the increase in net cash yield of crops, relative to that achieved through self- or windpollination, or with loss of a particular pollinator species or its habitat.

But pollination provides a further, supporting service to plants of no direct economic significance: this is harder to value.

\section{Financial costs are saved, imposed, or voluntarily undertaken elsewhere in the economy, through ecosystem effects}

This being the most widely used approach for regulating services, several examples are given. The common premise is that, without regulating services, expenditure would be needed either to achieve equivalent regulation, or to remedy the consequences of an unregulated system.

The avalanche protection afforded by Swiss forests exemplifies the former. Seymour and Girardet (1986) calculated that engineering works to give equivalent protection would cost $£ 200,000$ million (almost twice Switzerland's gross national product (GNP) at the time).

Imposed remedial costs are exemplified by floods, attention being recently focused by increased frequency of intense rainfall events, attributed to climate change, 
such that pre-existing protection no longer suffices. Illustrative calculations, drawn from an outline valuation of forests in the South-west Region of England are provided in Table 1 (Ekos et al., 2009).

These figures are highly provisional. Only thoughtful speculation informs estimates for non-insurable flood losses, for future flood frequency, for flood reduction by trees and for translation from flood reduction to flood damage reduction. There is danger in presenting such figures: for lack of other monetary calculations, they may be seized on and quoted, as though no caveats had been made. The data in Table 1 merely illustrate the kind of calculation required, and the large possible differences in result, even within reasonable assumptions.

The most intensively studied regulating effects are those on atmospheric $\mathrm{CO}_{2}$, and hence on global climate. Much present economic analysis concentrates on the relative costs of mitigation of $\mathrm{CO}_{2}$ levels by many options - of which, planting forests is one (Valatin and Price, 2014). Nijnik et al (2012) show that the cost of the forestry options is sensitive to location, forest productivity and the type of agriculture displaced.

Other major work examines the costs of continued accumulation of $\mathrm{CO}_{2}$, including:

- Mitigation costs, for example more temperature amelioration expenditure

- Damage costs, like those from increased storminess (as in Table 1)

- Health costs through heat stress or migration of disease zones. An additional 35,000 deaths were attributed to extreme temperatures in Western
Europe during the summer of 2003 (Stern, 2006). The Intergovernmental Panel on Climate Change (IPCC) (1996) calculated the cost of a life (in rich countries) at $\$ 1.5$ million. Although such figures are naturally controversial (especially if it is argued that these deaths would have been concentrated among elderly people with no "economic" life left), they potentially improve the case for reducing $\mathrm{CO}_{2}$ emissions.

- Defensive costs, like constructing sea walls. An untraced reference estimated that it would cost $\$ 130$ billion to build a sea wall sufficient to protect Bangladesh from the effects of $21^{\text {st }}$ century sealevel rise. This is approximately twice Bangladesh's present GNP.

- Retreat costs, like rebuilding cities in less vulnerable locations. Relocating a city like London, much of which lies close to sea level, could not cost less than several times the GNP.

Additional to these financial outlays are opportunity costs of lost agricultural production (approach (1) above), as through sea level rise, or water stress on plants. Europe's dry summer of 2003 caused an estimated $€ 15$ billion loss of agricultural production (Stern, 2006).

Trees also ameliorate microclimate. McPherson et al. (1999) estimated that a tree in a Californian urban area saved $122 \mathrm{kWh} /$ year in electricity used for air conditioning. Converted to cash value via the unit cost of electricity implies for the UK a value of $£ 17$ per tree per year. But the savings are highly sensitive to climate, configuration of

Table 1 One-year cost of "extreme" flood events, South-west Region

\begin{tabular}{|c|c|c|c|}
\hline Factor & Operator & Lower bound & Upper bound \\
\hline Insurable flood losses in England \& Wales (E\&W)* & & $£ 3000 \mathrm{M} / \mathrm{yr}$ & \\
\hline Non-insurable flood losses (guessed) & + & $£ 2000 \mathrm{M} / \mathrm{yr}$ & \\
\hline Total flood losses & $=$ & $£ 5000 \mathrm{M} / \mathrm{yr}$ & $£ 5000 \mathrm{M} / \mathrm{yr}$ \\
\hline Return period of extreme events (guessed) & $\div$ & 10 years & Annual \\
\hline Annual extreme event losses & $=$ & $£ 500 \mathrm{M} / \mathrm{yr}$ & $£ 5000 \mathrm{M} / \mathrm{yr}$ \\
\hline South-west Region: 9\% E\&W population 16\% E\&W land area hence (approximately) & $\times$ & \multicolumn{2}{|c|}{$12 \%$ of national damage } \\
\hline Apportioned damage & $=$ & $£ 60 \mathrm{M} / \mathrm{yr}$ & $£ 600 \mathrm{M} / \mathrm{yr}$ \\
\hline Extreme event flood reduction by "optimally located trees" $\dagger$ & $\times$ & $5 \%$ & \\
\hline \% trees "optimally located" $\ddagger$ & $\times$ & $8.9 \%$ & \\
\hline Extreme event flood reduction by "full tree cover" $†$ & $x$ & & $36 \%$ \\
\hline \% "full woodland cover" $\ddagger$ & $x$ & & $8.9 \%$ \\
\hline Area of tree cover & $\div$ & 212000 ha & \\
\hline Reduction of flood damage & $=$ & $£ 1.3$ / ha / year & $£ 91$ / ha / year \\
\hline
\end{tabular}

* Environment Agency (2007)

† Flood Risk Management Research Consortium (2008). Flood damage reduction is considered proportional to physical flood reduction, in absence of better quantification.

\# On the assumption that the $8.9 \%$ tree cover is presently located randomly, rather than optimally, in respect of flood reduction. 
trees (street trees vs peri-urban forest) and culture of energy use.

These illustrative calculations clarify that:

- the value of ecosystem services may significantly improve the economics of planted forests, but

- vary with context and assumptions; and that

- difficulties may lie less in the economics, than in the environmental science connecting land use change with its physical consequences for humans.

Costs (including opportunity costs) of past decisions, made to favour non-market benefits or abate non-market costs, indicate presumed benefit, or cost

A sample calculation, concerning restoration of mire ecosystems on the England/Scotland border, is given in Table 2. Before the importance of these ecosystems was recognised, planting with commercial Sitka spruce (Picea sitchensis (Bong.) Carr) had lowered the water table sufficiently to change the Sphagnum-dominated vegetation, with loss of characteristic mire species. It was decided not to replant 600 ha after felling the initial crop, with loss of all future timber revenues (and costs of obtaining them). This would have been rational only if the ecosystem benefits exceeded the lost net revenue.

This calculation assumes no discounting of cash flow. With a $6 \%$ discount rate (which was mandatory when the decision was taken), the calculations look very different. Since plantation forestry under this discount rate is unprofitable, there is an annual net benefit, $£ 11,400$, in not replanting. Again, the implicit value of the mires' regulating and supporting services depends critically on which set of assumptions is made. In this case, as often, the discount rate is the key variable (Price, 1993; UK Treasury, nd).

In any case, the premise behind this approach only succeeds if past decisions were taken with good

Table 2 Implicit value of the supporting services of a Border mire

\begin{tabular}{lc}
\hline Factor & Magnitude \\
\hline Annual yield & $10 \mathrm{~m}^{3} / \mathrm{ha}$ \\
Rotation & 40 years \\
Price $/ \mathrm{m}^{3}$ & $£ 15$ (after harvesting costs) \\
Establishment cost & $£ 800 / \mathrm{ha}$ \\
Management cost & $£ 5 / \mathrm{ha} / \mathrm{yr}$ \\
Mean annual revenue & $£ 15 / \mathrm{m}^{3} \times 10 \mathrm{~m}^{3} / \mathrm{ha}=£ 150 / \mathrm{ha}$ \\
Establishment cost $\div$ rotation & $£ 20 / \mathrm{ha} / \mathrm{yr}$ \\
Mean annual earning & $£ 150-£ 20-£ 5=£ 125 / \mathrm{ha}$ \\
Area affected & $600 \mathrm{ha}$ \\
Total annual opportunity cost & $£ 75000$ \\
\hline
\end{tabular}

Source: own calculations, based on historic Forestry Commission advice understanding of both the science and the economics of the system. The questions are therefore raised:

- were past decision-makers well informed?

- were decisions taken entirely for the benefit of society?

- why can present decision makers not use similar information, to make a primary decision, rather than deriving valuations from past decisions?

Similar products are marketed elsewhere in the economy Forests support in situ gene conservation, not only for identified human benefit, but to underpin continuing ecosystem functionality. These benefits are sometimes called "quasi-option values" in the economics literature, though much confusion exists over categories of biodiversity value $)^{i}$. Such services are purchased neither at source (in the forest) nor at the point of delivery (because the precise beneficent properties remain unidentified).

Nonetheless, similar services do seem to be sold in botanical gardens, where a broad spread of genetic material may be cultivated, and an entrance fee - typically several pounds, euros or dollars per visitor - may be charged. Here, however, a problem arises that dogs attempts to link actual payment to actual value. People visit botanical gardens to gain various services, among which cultural values may be more important than supporting values. Moreover, supporting values may be enjoyed by "free-riding" on the contributions of others - even if I don't pay to visit a botanical garden, I am not excluded from the values of either in situ or ex situ gene conservation: the benefits of functioning ecosystems accrue to all human beings. Although Marwell and Ames (1981) argue that not everyone freerides all the time, undoubtedly some people, perhaps the majority, do so for some, and perhaps for most, of the time, if that option is available.

The further problem exists, of whether conservation of a particular genetic base depends on maintenance of a particular ecosystem configuration at a particular place; or whether that base might survive sufficiently under different land uses or in different locations. Such possibilities greatly reduce the value legitimately attributed to any particular act of gene conservation (Simpson et al., 1996).

Voluntary subscriptions are made to related causes Despite free-riding, people do make voluntary subscriptions to support ecosystem services: by contributions in collecting boxes on site, on the streets, or at their doors. They join bodies like the UK Woodland Trust, whose properties are nonetheless open to non-members. They buy provenanced or organic food, and fairly traded clothing, and products made from certified timber - not 
for better product performance, but because they prefer the mode of production.

The theory of economically rational behaviour attributes such free-will offerings to the "warm glow" that arises from "acting rightly" or "being seen to act rightly". It gives genuine satisfaction to individuals who contribute, which is denied to whomsoever does not contribute: it is a classical private good, susceptible to market valuation.

How this value relates to real improvement in delivery of ecosystem services is discussed in the section on certification premiums.

Consumer-citizens are asked their willingness to pay for a product, or the compensation required for suffering a "bad"ii

This "stated preference" approach, attributed to Davis (1963), is most commonly applied and known from contingent valuation, the subject of thousands of published papers. It is, potentially, flexible, allowing any existing environmental condition to be encapsulated, and contrasted with any hypothetical alternative condition. For example, a photograph of a coastal forest of Corsican pine in North Wales could be contrasted with a version manipulated digitally to remove the tree cover. The question might be asked: "What would you be willing to pay to maintain the sand-dune stabilising functions of this forest?" The hypothetical alternative to maintaining the supporting services is whatever would be provided by the landscape without the forest.

The answer obtained depends critically on how the question is phrased. The same with-and-without pictures could accompany a question such as "What would you be willing to pay to remove the influence of these alien conifers from this landscape?" Unfortunately, the question's phrasing may depend on who sponsors the research, and what their agenda might be.

Such political problems apart, many difficulties remain for honest, unbiased researchers in eliciting an honest, unbiased answer: these are a major preoccupation of the literature. Confronting a respondent with a trade-off between good environment and a range of willingnesses to pay may prompt a desire to show general concern for the environment: thus the highest suggested sum of money may be selected. An obvious further difficulty lies in separating willingness to pay for regulating and supporting services, from willingness to pay for the aesthetic impressions comprising cultural services.

Some formats of question seek to avoid these problems by offering choice among packages, each of which offers different levels of several environmental attributes and different monetary sums: this diminishes the environment-versus-money polarisation, and enables exploration of which attributes are actually valued.
But problems with symbolic values remain. Nielsen et al (2007) found high willingness to pay for a forest containing standing deadwood, but only the smallest offered amount of it. The authors suggest that this represents a symbolic gesture towards the supporting services that deadwood offers to detritivores, without excessively compromising a personal preference for the cultural service of a tidy, well-managed woodland.

Also advocated (Ovaskainen and Kniivilä, 2005) are contingent referendum formats, where respondents are asked to vote on a proposal offering both higher levels of environmental quality and higher amounts of taxation. This format seemingly brings decisions into the realm of altruistic public choice, rather than self-centred pursuit of personal gain. Price (2006a) suggested, however, that such citizen responses, carefully elicited, may actually give the researcher what is needed: a true valuation of personal benefit from ecosystem services.

These and other issues in stated-preference approaches are further discussed in the section on information bias.

\section{Decision makers or experts ask themselves questions as in the section above, or get a "feel" for acceptable answers}

The above difficulties may be circumvented by decision makers' introspection about their own willingness to pay. This also avoids time and effort spent in eliciting responses from individuals, many of whom have deep difficulty with the concept of trading environment against money (Clark et al., 2000).

Consider the question "What would it be reasonable for me personally to pay for the song of a nightingale, and for the reproductive strategy for genes that it represents?" An unreasonably large answer might be $£ 1$ million, and an unreasonably small one, 10 pence. It then only remains to define the range within which a reasonable answer might lie. The problem once again, however, lies in segregating values attributable to supporting services for the gene pool, and to cultural services to the observer.

This approach is more appropriate to cultural services, but here arises another problem, of how representative an expert is of the wider population's values. Clearly an expert ornithologist, through inclination and training, would value bird-song in an appropriate habitat, more highly than would the population generally.

Arguably also, where experts have superior expertise and insight, they should use those, rather than gut feeling, to value supporting services, via approaches such as those described above.

One case where expert valuation has become embedded is the Helliwell system for valuing amenity trees, based on expertly judged tree characteristics (Helliwell, 1967; 
Arboricultural Association, 2008). By explicitly stating its value assumptions, it has gained professional consensus and thus consistency. An equivalent, though less used, system exists for woodlands, described in the Arboricultural Association publication.

\section{Willingness to pay is analysed for market goods that provide access to non-market goods}

Within this approach, the hedonic pricing model is popular. It hypothesises that willingness to pay for a bundle of services, as embodied in house purchase, reflects the bundle's attributes: for example size and quality of building and its locational attributes. The aesthetic qualities that trees impart to a landscape form one attribute. Statistical analysis of sale prices for houses offering diverse combinations of attributes allows a value to be assigned to each attribute. First applied by Payne and Strom (1973) to street trees, the approach was extended to planted forests by Willis and Garrod (1992), and it excited media attention when reproduced in the National Ecosystem Assessment (Watson and Albon, 2011).

For urban trees and peri-urban forests, the cultural services are the ones most readily and commonly valued, since many regulating and supporting services are available to consumers without purchase of a house located close to the trees (microclimate amelioration being the exception). Price (2012) gave a critique of hedonic pricing of the cultural attributes of trees, drawing particular attention to how composition of elements, such as trees and rivers, influences aesthetic quality, but may not be - perhaps cannot be - represented among the attributes.

Collinearity between attributes is also a problem. For example, houses benefiting from views over a river (positively valued) may also be more liable to flooding (negatively valued). Obversely, the tendency of good views and appropriate tree planting to attract wealthy purchasers creates a "good neighbourhood" effect that spuriously enhances the derived good-view premium (Price, 1995).

The hedonic pricing model has potential in evaluating regulating services, for example in terms of the price discount on houses liable to flooding. However, it does not offer a direct valuation of forests' role in ameliorating floods. To achieve this requires further investigation, using approaches outlined in the section on financial costs.

\section{Some surprising case study results}

The ethos of ecosystem services valuation has, since the topic became fashionable, suggested that the process will favour maintenance of ecosystems generally (Watson and Albon, 2011). However, not all outcomes are as might be desired or expected. The following sections present some selected results.
Information bias: the more you tell them, the more they act like experts

In the 1980s, afforestation of Scotland's Flow Country became a major UK issue. Valuing the wetland habitat, and how land use change affected it, became a target for contingent valuations (Hanley and Craig, 1991).

The received wisdom, then, was that respondents to questionnaires should be given information about the ecosystem they were valuing, to allow informed evaluation (Hanley, 1995). Typically, stated values increased with the amount of information given (though Price (2001) recorded an explicably contrary result).

In one exercise - intended to explore the weaknesses of the method rather than to derive a meaningful answer respondents were asked their willingness to pay to maintain the ecosystem in its pre-afforested condition (Price, 1999). More information was given, and the question repeated, with the usual higher valuation. Respondents were then asked to divide their value among various categories of ecosystem services: regulating and supporting ones, various aspects of cultural ones, and the intrinsic values which have been the object of much misunderstanding (Price, 1997). Values from the sample were initially scaled up to the population of Western Europe, which it could be argued was the relevant one, since the area supported half the European breeding population of one species, the greenshank (Tringa nebularia (Gunnerus)). Some results are presented in Table 3.

The aggregate value, almost $£ 68$ billion, was nearly $10 \%$ of the UK's then GNP. This, if taken seriously, would have constituted an invincible case against afforestation, and led to suspicion that the valuation was symbolic: respondents were loading general concern for environmental conservation onto this issue, because the questionnaire offered their only opportunity to express that concern.

Much willingness to pay was allocated to cultural services and intrinsic values, and some to services which should have been included in other valuations (Price (1999) gives details). The remaining value was attributed to various regulating and supporting services. But a question now arises: even after a summary had been given of the ecosystem's significance (but not of how afforestation would affect it), how could respondents realistically evaluate such services? Environmental scientists and economists may spend a lifetime on trying to understand these things, and at the end would admit that they understand them but imperfectly. What therefore is actually being valued is not regulating and supporting services in themselves, but the value placed by the respondents on their knowing of those services, and a warm glow attributed to doing what they could to maintain those services. Consumer-citizens should assist in valuing the services themselves, not by considering 
Table 3 A breakdown of the value ascribed to preserving the Flow Country

\begin{tabular}{lcc}
\hline Components included in value & Aggregate value (fmillion) & Proportion of initial value (\%) \\
\hline All & 67900 & 100 \\
Cultural service values & 23300 & 34 \\
Doubled-counted values & 7500 & 11 \\
Intrinsic values & 16600 & 24 \\
Regulating/supporting values & 20500 & 30 \\
\hline... for those with prior knowledge & 3062 & 4.5 \\
... adjusted to geographical zones & 545 & 0.9 \\
... at pre-information level & 307 & 0.5 \\
\hline
\end{tabular}

Source: modified from Price (1999)

habitat and processes, but through willingness to pay for the results of regulation and support (freedom from flooding, products of agriculture etc), as embodied in the approaches outlined in the sections above on marketable benefits and financial costs.

Supposing that a warm glow is what respondents evaluate. To what population is it relevant? The answer is, only the people who are aware of the Flow Country and the issues surrounding it, and thus who could feel the warm glow about the preservation of the habitat. The extent of knowledge of the Flow Country was tested by asking respondents directly whether they knew it. Because they might prefer to appear knowledgeable rather than ignorant, their real familiarity was tested by asking them to identify characteristics of the area. The responses made clear that many were thinking of the Low Countries: only the proportion of the sample who evidently did know about the Flow Country was included as relevant. (This is the correct means of dealing with the much-discussed so-called aggregation problem: bulking up questionnaire responses to the appropriate population. It avoids artificial definition of the spatial limits of relevant population, without requiring the absurd assumption that all Earth's inhabitants are equally affected by what may be a very local issue.)

The answer was refined by disaggregating the respondent population according to their geographic origins, and applying the proportion of aware respondents in each origin to its population. Because the highest level of awareness was found only in the small Scottish population, this further reduced value.

Finally, willingness to pay was reduced to the pre-information level, which would be typical of the vast majority of the population who did not encounter the questionnaire. The resultant figure for regulating and supporting services was only $0.5 \%$ of the total value initially derived.

Because of symbolic response, even this figure would be overstated. The warm glow is implanted by focusing environmental concern onto a particular ecosystem. This warm glow would doubtfully be maintained for the Flow Country: it would be transferred when other conservation issues came to the forefront of respondents' minds, with the advent of some other controversy.

By giving scientific information about regulating and supporting services, the questionnaire seems to redefine the role of respondents, as "scientific experts" (a role which they could not reasonably fulfil). It appears to absolve real experts of the need to value processes and conditions, and replaces that with responses from the public that could never be better than a wild guess. And yet experts still feel they should promote an educated wild guess: so, within the present ethos of consumer-citizen valuation, they may favour imparting a thimbleful of knowledge.

Afforestation of the Flow Country might not have been beneficial: the provisioning services were of limited value in a severe environment; carbon loss from the peaty soil might have outweighed that gained in tree biomass. But the value of preserving the status quo was here much exaggerated by uncritical application of the consumercitizen questionnaire approach outlined above. In particular, effects on regulating and supporting services of both the pre-existing wetland ecosystem, and of its forest replacement, should have been evaluated through other approaches, applied by experts.

\section{Certification premiums: selling the unknown}

Stated or revealed willingness to pay a premium for certified timber represents a similarly contestable role for consumer-citizens, but within the context of the voluntary subscriptions approach outlined above. To translate willingness to pay for a product into willingness to pay for ecosystem services requires both that researchers know how much of the premium is attributed by consumers to enhanced ecosystem services, and that consumers themselves know how their payment relates to actual service delivery.

A pilot questionnaire on motivations for paying a premium for certified timber received responses as in Table 4. Many responses related to processes other than delivering ecosystem services.

How paying a certification premium relates to quantitative service delivery is even less clear. Many respondents 
Table 4 A premium for what?

\begin{tabular}{lc}
\hline What do you feel you would be paying for? & $\begin{array}{c}\text { Number of } \\
\text { responses }\end{array}$ \\
\hline Ecological sustainability & 18 \\
Economic sustainability & 12 \\
Social sustainability & 11 \\
Friendliness of production process to & 9 \\
environment & 8 \\
Friendliness of production process to people & 14 \\
Assurance that logging had been done legally & 1 \\
Fair trade & 1 \\
Conscience money &
\end{tabular}

Source: Price (2006b)

claimed to know both the volume of timber required to make certified products, and the forest area and time-span needed to grow this volume. (They were less clear that certification would in fact secure the desired outcomes.) But the only respondent to express substantial ignorance about all these crucial mappings, from premium purchase to ecosystem service delivery, was a (realistic) professional expert in marketing and certification. Perhaps other respondents exaggerated their level of knowledge?

It is even doubtful whether product labelling was understood. Wieland (unpubl.) ${ }^{\mathrm{iii}}$ found that many respondents could not identify Forest Stewardship Council (FSC) or Programme for the Endorsement of Forest Certification (PEFC) logos; did not know the implication of FSC or PEFC registration; and even identified "dummy" logos as being associated with sustainability.

Consider further, that the benefit of enhanced ecosystem services, like climate protection associated with personal purchase of a unit of certified timber, accrues almost entirely to other world citizens (the free-rider problem again). Once again, willingness to pay for certified timber is most plausibly attributed to the warm glow given by acting rightly and responsibly towards planet and people.

Instead, follow through the alternative hypothesis: that certification creates a market for the regulating and supporting services of environmentally sustainable timber production, and that this market functions effectively according to the assumptions of neoclassical economics. Suppose enhanced ecosystem services deliver a narrowly self-interested benefit to the purchaser of certified timber (as is deemed to motivate economically rational people in a market system). Suppose that the premium willingly paid is only $€ 1$ per $\mathrm{m}^{3}$. If all the world's population benefits equally, this implies a total ecosystem service benefit of $€ 7$ billon per $\mathrm{m}^{3}$, and a benefit from all traded certified timber of around $€ 35$ million million millon. Such a figure is, of course, entirely implausible (it exceeds gross world product by a huge factor), yet it really is the arithmetical consequence of assuming that such markets for ecosystem services function in the neoclassical manner.
Next, consider the distribution of certification premiums. Suppose that a $20 \%$ price premium - representative of what has been found in surveys - exists on a certified product costing $€ 25$ and embodying $10 \mathrm{~kg}$ of roundwood. This translates into $20 \% \times € 25 \times 1000 / 10=$ $€ 500$ per tonne of roundwood. But the actual premium enjoyed by certified timber producers ranges from $€ 1$ to $€ 3$ per tonne. This hardly translates willingness to pay for ecosystem services, into an adequate incentive for their delivery.

Hence certification seems to provide neither an efficient value marker for the ecosystem services created by certified forest management, nor an equitable distribution of payment for those ecosystem services. (Following that second point, payments made in one reduced impact logging project included no element for added operational inputs, and so penalised the workers implementing the project (Healey et al., 2000).)

If consumers have little idea how the certification premium relates to quantitative delivery of ecosystem services, willingness to pay the premium is best interpreted as a warm glow value for behaving ethically. There is an implied request, that those who have appropriate expertise should use other approaches (such as those outlined in the sections above on marketable benefits and financial costs) to estimate the actual value of regulating and supporting services - and of all the social conditions and processes which payers of certification premiums also desire.

\section{Disservices to hydroelectricity}

Foresters have long known that forests can ameliorate distribution of catchment runoff. Hydrologists have also long known that conifers planted on windy, high rainfall sites reduce total runoff. Law (1956), a water supply engineer, reported reduced stream flow into a reservoir whose catchment had been afforested. Hydroelectric engineers reported less generation than was expected from gross rainfall figures. The mechanisms of rainfall interception and re-evaporation were investigated by Calder and Newsom (1979) for the UK, reproducing results found in other high rainfall environments.

Such losses compromise the energy balance for forests planted on hydroelectric catchments. One sample revealed a loss, over one forest rotation, of about $10^{12}$ joules per ha, calculated as the extra energy input required at thermal power stations, to replace the loss (Barrow et al., 1986). Extensive sampling in the Scottish Highlands found that lost streamflow reduced the number of afforestation sites found profitable, from 11 out of 41 to 5 out of 41 (with only direct cost of forgone generation) and to 3 out of 41 (including environmental damage from thermal generation). Clear policy guidelines arose from this ecosystem disservice of planted forests: avoid afforesting hydroelectric catchments altogether; or, if not possible, concentrate 
planting at sites of moderate rainfall, on catchments whose hydroelectric schemes have low operating heads.

These results were never, to the authors' knowledge, contested; but neither were they accepted. Pearce (1991) stated that "the data are not currently in a form that enables valuation". And that misleading assertion has remained as the conventional wisdom of UK foresters to this day.

\section{Carbon benefits turned on their head}

Carbon sequestration is prominent among the regulating services of expanded forest area. At first sight it might seem that benefits would be even greater, if the price attributed to a carbon flux, into or out of the atmosphere, were rising. Several reasons can be given for such a rise. On the demand side, atmospheric $\mathrm{CO}_{2}$ may do more damage through time, because a greater gross world product and world population will be adversely affected. On the supply side, abatement cost might rise, as the most cost-effective measures are taken first, leaving progressively more costly measures as the remaining options. Price might be forced up in markets driven by governmental requirements to achieve targets for net emissions reduction. Such predicted price rises are now mandated by some governments, for example, the UK Department of Energy and Climate Change (2009).

The case is not simple, however. A commercial forest cycle entails a period of sequestration, followed by revolatilisation of carbon when the crop is felled and its products decay or are burned (Price \& Willis, 2011). If revolatilisation occurs at higher prices than those for sequestration, the overall economic carbon account is negative.

This might seem just an accounting fiction, except that lagged transactions between forests, their products and $\mathrm{CO}_{2}$ sinks mean that a single forestry cycle leads to higher atmospheric $\mathrm{CO}_{2}$, two or three decades after final felling, compared with the "no-afforestation" baseline. Thermal inertia (particularly of the oceans) means that consequent warming and hence economic damage are further delayed. If these results occur at a time when one tonne of atmospheric $\mathrm{CO}_{2}$ really does cause higher economic costs than one tonne now, then the disservice of carbon volatilisation eventually outweighs the service of carbon sequestration. Taking a thinned crop of Sitka spruce with maximum productivity $12 \mathrm{~m}^{3}$ per ha per year, using coefficients of sink interaction and thermal inertia from the scientific literature, and projecting a $2 \%$ per year price rise for carbon, net cumulative benefit turns to net cost after 170 years.

This effect has not been noted previously, probably because economists normally discount future costs and benefits at a higher rate than any rate of price rise: thus future carbon fluxes are always "less important" than present-day ones. The surprising result described above is a joint consequence of both a high rate of price rise for carbon fluxes, and a low discount rate for them. The intuitive expectation might be that both these factors would improve the case for forestry, but this is not the outcome from methodical calculation using real-world data.

Creating a normal forest structure, with equal areas in each age class, does ensure that at no future time are there net $\mathrm{CO}_{2}$ emissions from a forest and its products, and thus never any higher atmospheric $\mathrm{CO}_{2}$ than would have existed without afforestation. Then, the economic carbon account is always positive. This emphasises the importance of viewing ecosystem services holistically, with sustained forest growth, exploitation and replacement. Here, foresters' customary perspectives have important lessons for environmental economists.

Price (in press) provides additional details from which these conclusions are derived.

\section{Conclusion: any morals for forest planters?}

Economic valuation of ecosystem services is not intrinsically hostile to the deliberate protection or enhancement of those services. On the other hand, such valuation does not invariably favour a particular ecosystem, such as a planted forest: there is potential for adverse, or surprising results. The approaches to valuation need to be applied, with due thought, in particular contexts. In some cases planted forests will be favoured: in others they will not be.

Cases have been described to illustrate the deployment of valuation approaches, and to confront problems that may arise. The aim has been to give balanced representation of cases that are, and are not, favourable to planted forests; and of cases where approaches deliver a useful result, and those where results may be misleading.

More research is needed of course. It must be free of generalised valuations and prescriptions. Ecosystem services should be valued in a specific physical and social context.

${ }^{i}$ Price, C (unpublished manuscript) Economic valuation of biodiversity: a consequentialist pilgrimage.

ii That is, any economic change which reduces wellbeing: the opposite of a good.

iii Wieland, D (unpubl.). From Voluntary Certification to Legislation: Preventing Trade in Illegally Obtained Timber; and do the Public Really Know what they are Purchasing when making Ethical Choices? Draft thesis, Bangor University.

Competing interests

The author declares that he has no competing interests. 


\section{Acknowledgements}

I am grateful for the efforts of two anonymous reviewers and Eleanor Price, in helping to sharpen this paper's arguments.

\section{Declaration}

Publication of this supplement was funded by the New Zealand Forest Research Institute Limited (trading as Scion).

This article has been published as part of JOURNAL Volume 44 Supplement 1, 2014: Proceedings of the Third International Congress on Planted Forests. The full contents of the supplement are available online at http://www. nzjforestryscience.com/supplements/44/S1.

Published: 26 November 2014

\section{References}

Arboricultural Association: Visual amenity valuation of trees and woodlands: the Helliwell system. Romsey, UK: Arboricultural Association; 2008. Barrow P, Hinsley AP, Price C: The effect of afforestation on hydroelectricity generation: a quantitative assessment. Land Use Policy 1986, 3:141-151. Calder IR, Newson MD: Land-use and upland water resources in Britain - a strategic look. Water Resources Bulletin 1979, 15:1628-39.

Clark J, Burgess J, Harrison C: "I struggled with this money business": respondents' perspectives on contingent valuation. Ecological Economics 2000, 33:45-62.

Davis R: Recreation planning as an economic problem. Natural Resources Journal 1963, 3:239-49.

Department of Energy and Climate Change: The UK low carbon transition plan: national strategy for climate and energy. London: The Stationery Office 2009. Eastwood A, Nijnik M, Brooker R, Pakeman R, Artz R, Norton L, Ross L, Bullock J, Vellinga N, Albon S, Fielding D, Irvine RJ, Ramsay S, Cooksley S: Nature conservation and ecosystem service delivery. In JNCC Report. Volume 492. Peterborough, UK: JNCC; 2013.

EKOS Lockhart Garratt Ltd, Price C: South West England Woodland \& Forestry: Strategic Economic Study. Manchester, UK: Ekosgen; 2009.

Environment Agency: Review of 2007 Summer Floods Bristol, UK: Environment Agency; 2007.

Flood Risk Management Research Consortium: Impacts of upland land management on flood risk: multi-scale modelling methodology and results from the Pontbren experiment Manchester, UK: University of Manchester; 2008. Hanley N: The role of environmental valuation in cost-benefit analysis. In Environmental Valuation: New Perspectives. Wallingford, UK: CAB International;KG Willis, \& JT Corkindale 1995:39-55.

Hanley N, Craig S: Wilderness preservation and the Krutilla-Fisher model: the case of Scotland's Flow Country. Ecological Economics 1991, 4:145-64. Healey JR, Price C, Tay J: The cost of carbon retention by reduced impact logging. Forest Ecology and Management 2000, 139:237-55.

Helliwell DR: The amenity value of trees and woodlands. Arboricultural Journal 1967, 1:128-31

IPCC: Economic and Social Dimensions of Climate Change. Cambridge, UK: Cambridge University Press; 1996.

Kittredge J: Forest Influences. New York: McGraw-Hill; 1948.

Law F: The effect of afforestation upon the yield of water catchment areas. Journal of the British Waterworks Association 1956, 38:489-94.

Marwell G, Ames RE: Economists free ride, does anyone else? Experiments on the provision of public goods IV. Journal of Public Economics 1981, 15:295-310. McPherson EG, Simpson JR, Peper PJ, Xiao Qing Fu: Benefit-cost analysis of Modesto's municipal urban forest. Journal of Arboriculture 1999, 25:235-48.

Millennium Ecosystem Assessment: Ecosystems and human well-being: synthesis Washington, DC: Island Press; 2005.

Nielsen $A B$, Olsen SB, Lundhede T: An economic valuation of the recreational benefits associated with nature-based forest management practices. Landscape and Urban Planning 2007, 80:63-71.

Nijnik M, Pajot G, Slee B, Moffat A: An economic analysis of the establishment of forest plantations in the United Kingdom to mitigate climate change. Forest Policy and Economics 2012, 26:34-42.

Ovaskainen V, Kniivilä M: Consumer versus citizen preferences: evidence on the role of question framing. Australian Journal of Agricultural and Resource Economics 2005, 49:379-94.

Payne BR, Strom S: The contribution of trees to the appraised value of unimproved residential land. Valuation 1973, 22(2):36-45.
Pearce D: Forestry expansion: a study of technical, economic and ecological factors No.14, Farnham, UK: Forestry Commission 1991.

Price C: Time, discounting and value. Oxford, UK: Blackwell; 1993, Also freely available in electronic format from http://c.price@bangor.ac.uk.

Price C: Pros and cons of alternative evaluation methods. In Environmental valuation: new directions. Wallingford, UK: CAB International;KG Willis \& J Corkindale 1995:160-77.

Price C: Valuing biodiversity: what, how and by whom? Scottish Forestry 1997, 51:134-142.

Price C: Contingent valuation and retrograde information bias. In The living forest Proceedings of the International Symposium on the non-market benefits of forestry. London: The Stationery Office;A Park \& C Stewart Roper 1999:37-44. Price C: Exact values and vague products? Contingent valuation and passive use value. In Forest and Social Services - the Role of Research, Research Paper 815. Vantaa, Finland: Finnish Forest Research Institute;T Sievanen, CC Konijnendijk, L Langner, \& K Nilsson 2001:205-217.

Price C: Superficial citizens and sophisticated consumers: what questions do respondents to stated preference surveys really answer? Scandinavian Forest Economics 2006a, 41:285-96.

Price C: Buying certification: pigs in pokes, warm glows, and unexploded bombs. Scandinavian Forest Economics 2006b, 41:265-272.

Price C: Subjectivity and objectivity in landscape evaluation: an old topic revisited. In The Economic Value of Landscapes. London: Routledge; $\mathrm{M}$ van der Heide, \& W Heijman 2012:53-76.

Price C: Rising carbon flux price and the paradoxes of forest-based reduction of atmospheric carbon stock: an extended summary. Scandinavian Forest Economics 45, in press.

Price C, Willis R: A review of farm woodland research. Report to Ministry of Agriculture, Fisheries and Food London 1994, Available from c.price@bangor.ac.uk. Price C, Willis R: The multiple effects of carbon values on optimal rotation. Journal of Forest Economics 2011, 17:298-306.

Seymour J, Girardet H: Far from paradise London: BBC Publications; 1986. Simpson RD, Sedjo RA, Reid JW: Valuing biodiversity for use in pharmaceutical research. Journal of Political Economy 1996, 104:163-185.

Stern N: The economics of climate change. London: The Stationery Office 2006, Also at http://www.hm-treasury.gov.uk/media.BAC/Executive.

UK Treasury (nd): The Green Book: Appraisal and Evaluation in Central Government. London: The Stationery Office.

Valatin G, Price C: How cost-effective is forestry for climate change mitigation? In Challenges and opportunities for the world's forests in the 21st Century. New York: Springer;Fenning, T 2014:297-339.

Watson R, Albon S: UK national ecosystem assessment: synthesis of the key findings. Cambridge: UNEP-WCMC; 2011.

Willis KG, Garrod GD: Amenity value of forests in Great Britain and its impact on the internal rate of return from forestry. Forestry 1992, 65:331-46. Willis KG, Garrod G, Scarpa R, Powe N, Lovett A, Bateman IJ, Hanley N, Macmillan DC: The social and environmental benefits of forests in Great Britain. Edinburgh: Forestry Commission 2003.

doi:10.1186/1179-5395-44-S1-S5

Cite this article as: Price: Regulating and supporting services and disservices: customary approaches to valuation, and a few surprising case-study results. New Zealand Journal of Forestry Science 2014 44(Suppl 1):S5.

\section{Submit your manuscript to a SpringerOpen ${ }^{\mathcal{O}}$ journal and benefit from:}

- Convenient online submission

- Rigorous peer review

- Immediate publication on acceptance

- Open access: articles freely available online

- High visibility within the field

- Retaining the copyright to your article

Submit your next manuscript at $>$ springeropen.com 